\title{
Root Restriction Affects Shoot Development of Peach in a High-density Orchard
}

\author{
J.G. Williamson ${ }^{1}$ \\ Fruit Crops Department, Institute of Food and Agricultural Sciences, University of Florida, \\ Gainesville, FL 32611 \\ D.C. Coston ${ }^{2}$ \\ Department of Horticulture, Clemson University, Clemson, SC 29634-0375 \\ J.A. Cornell ${ }^{3}$ \\ Department of Statistics, Institute of Food and Agricultural Sciences, University of Florida, \\ Gainesville, FL 32611 \\ Additional index words. Prunus persica, planting method
}

\begin{abstract}
Planting treatments were evaluated for their influence on shoot development and root distribution of ownrooted 'Redhaven' peach [Prunus persica (L.) Batsch] trees planted to high density (5000 trees/ha). Planting in fabriclined trenches (FLT) or narrow herbicide strips (NHS) reduced the diameter and length of primary shoots, the number and combined length of second-order shoots, and the total length of shoots. Flower density, the number of flowers per node, and the percentage of nodes containing one or more flowers were increased for FLT trees but not for NHS trees when compared with controls. The length of primary shoots increased quadratically for all treatments with increasing limb cross-sectional area (LCA). The total length of shoots increased more with increasing LCA for controls than for FLT trees. The number of flowers per shoot increased linearly for all treatments with increasing LCA values. Root concentration decreased with increasing soil depth and distance from tree rows for all treatments. Reduced widths of weed-free herbicide strips had little effect on root distribution. Roots of FLT trees were reduced in number and restricted vertically and laterally when compared with other planting treatments. The FLT treatment modified shoot development by reducing the length of total shoots and length of primary shoots across LCA values measured when compared with NHS and control-treatments.
\end{abstract}

Many high-density planting systems have been evaluated for peach. The peach meadow orchard system (Erez, 1976) and various modifications of it (Erez, 1982, 1985) have potential for early ripening cultivars in regions with relatively long growing seasons. Research in Italy demonstrated advantages of highdensity peach orchards trained to a free spindle system (Bargioni et al., 1983, 1985). In Australia, the Tatura trellis (Chalmers et al., 1978) and regulated irrigation (Chalmers et al., 1981) have been used to manage high-density peach orchards.

Managing vegetative and reproductive growth and controlling tree size are important aspects of high-density orchard culture. Dorsey (1935) reported that peach node development and associated flower bud formation are related to vegetative vigor. The potential for flower bud formation increased with increasing vegetative growth except when growth was excessive; then flower bud development was suppressed. Chalmers et al. (1981) suggested that vegetative growth of peach occurring late in the growing season competes with reproductive growth during stage 3 of fruit development. We have observed excessive vegetative growth, suppressed flower bud development, and reduced fruit size in peach meadow orchards and other high-density orchard systems in South Carolina, where pruning and tree-to-tree competition were used to control tree size.

Growth and distribution of tree roots can affect development

Received for publication 1 Aug. 1991. Accepted for publication 23 Jan. 1992. Technical contribution no. 3148 of the South Carolina Agricultural Experiment Station, Clemson Univ. We thank C.H. Mathews, R.Y. Fleming, and B.B. Stancell for assistance with orchard establishment and data collection. The cost of publishing this paper was defrayed in part by the payment of page charges. Under postal regulations, this paper therefore must be hereby marked advertisement solely to indicate this fact.

'Assistant Professor.

${ }^{2}$ Professor.

${ }^{3}$ Professor. of aerial plant organs. Cockcroft and Wallbrink (1966) reported peach tree vigor to be related to the volume of soil readily accessible to the root system. Richards and Rowe (1977) reported that root restriction of hydroponically grown peach seedlings reduced shoot and root growth similarly so that root : shoot ratios were not affected. Exogenous applications of benzylaminopurine largely overcame the effects of root restriction. They suggested that roots exert control over shoot growth by synthesis and/or translocation of a growth substance(s), probably cytokinin. Natural root restriction has allowed others to regulate peach tree growth in the field by irrigation (Chalmers et al., 1981; Mitchell and Chalmers, 1982).

The horizontal and vertical distribution of peach root systems can be extensive in humid regions of the United States (Havis, 1938). Acceptable tree size control and enhanced yield efficiency have been achieved in a high-density peach orchard where modified planting procedures were used (Williamson and Coston, 1990). Other preliminary findings (Dolph and Proebsting, 1989) have suggested that root restriction may also effectively reduce tree size of apple [Malus domestics (Borkh.)] and cherry [Prunus avium (L.)].

Our objective was to determine the effects of planting treatment on root distribution and vegetative and reproductive development of peach shoots in a high-density peach orchard. Vegetative and reproductive growth of peach shoots are compared for trees with restricted and nonrestricted root systems.

\section{Materials and Methods}

A high-density peach orchard (5000 trees/ha) was established during Summer 1984. The site consisted of well-drained, mod-

Abbreviations: FLT, fabric-lined trenches; LCA, limb cross-sectional area; NHS, narrow herbicide strips. 
erately permeable Cecil and Appling soils. Each is classified as clayey, kaolinite, Thermic Type Hapludults. Own-rooted 'Redhaven' peach trees, propagated from hardwood cuttings the previous winter, were planted at an in-row spacing of $1 \mathrm{~m}$ with 2 $\mathrm{m}$ between rows. A detailed account of orchard preparation and site characteristics was reported by Williamson and Coston (1990).

The initial design consisted of seven randomized complete blocks each containing ten 15 -tree plots. Five planting treatments were assigned completely at random to the plots (each treatment was assigned to two plots not necessarily next to each other) so that two irrigation levels could be imposed per planting treatment in 1986. The result was a five planting treatments $\mathrm{x}$ two irrigation levels factorial arrangement within each block.

The five planting treatments used were: 1) Control, trees set in holes dug with a shovel; the holes were just large enough to accommodate root systems; 2) auger, trees set in 45-cm-deep holes dug with a 20-cm-diameter auger; 3 ) raised bed, top soil pulled from between rows into rows to form beds $\approx 1.0 \mathrm{~m}$ wide and $20 \mathrm{~cm}$ high; trees were centered on beds; 4) NHS, trees planted as controls in 0.5 -m-wide herbicide-treated strips; herbicide strips for all other treatments were maintained at a width of $1.0 \mathrm{~m}$; and 5) FLT, trees planted in V-shaped trenches 90 $\mathrm{cm}$ wide $\mathrm{x} 30 \mathrm{~cm}$ deep that were lined with a polyester fabric impregnated with an acrylic latex (Trevira Spunbond no. 533251; American Hoechst Corp., Atlanta, Ga.). Weed-free herbicide strips were maintained with repeat applications of paraquat.

Overhead and drip irrigations were used during the 1984 season. During the 1985 growing season, all treatments received 35 liters water/week per tree via drip irrigation, consisting of one emitter per tree located 20 to $30 \mathrm{~cm}$ from the trunk. In Spring 1986, two irrigation levels were imposed. Half of the plots of each planting treatment received a high irrigation level that replaced $100 \%$ of the estimated daily evapotranspiration (ET) during all stages of fruit development based on class A evaporation pan readings with an estimation of canopy area and a crop coefficient of 0.7 . The other half received a low irrigation level that replaced $12.5 \%$ of the estimated ET during stages I and II of fruit growth and 100\% of estimated ET during stage III.

Shoot measurements. In Spring 1986, diameter and length of shoots, number of nodes per shoot, number of second-order shoots per primary shoot, and number of single and paired flowers were recorded from four shoots randomly selected from each of three trees per treatment in seven replicate blocks. In Spring 1987, similar data were collected from 12 shoots on each of three trees per treatment, replicated three times for the control, NHS, and FLT trees. These treatments were selected for further study because of growth differences observed during 1986.

Data from 1986 were analyzed using the General Linear Models (GLM) procedure of the Statistical Analysis System (SAS, 1982) and means were separated by Duncan's multiple range test at $P=0.05$. Data collected in 1987 were analyzed by fitting regression equations using PROC REG of the SAS (1982). The length of primary shoots, the combined length of second-order shoots, the total length of shoots (length of the primary shoot plus the combined length of associated second-order lateral shoots), and the number of flowers per shoot were regressed on LCA. A log transformation of the total shoot length was used in the regression analysis because of increased variability of this response variable at larger LCA values.

Root measurements. During Feb. 1987, root systems of the control, NHS, and FLT treatments were examined using the trench profile technique (Bohm, 1979). These three treatments were chosen for root distribution studies because of differences in growth of aerial plant parts observed between 1985 and 1987. Each planting treatment was evaluated under both irrigation levels. Trenches $2 \mathrm{~m}$ long x $1.5 \mathrm{~m}$ deep were dug perpendicular to tree rows for four trees in each planting treatment/irrigation level combination. All trees evaluated for root distribution were located in the middle row of each plot and surrounded on all sides by trees of the same planting treatment/irrigation level combination. The trench walls closest to the trees were used. They were $\approx 20 \mathrm{~cm}$ east of tree trunks and intersected the wetted zones of the drip emitters. Spades and hand trowels were used to smooth the trench wall. Cut roots were exposed by removing $<3 \mathrm{~cm}$ of soil from the wall surface with high-pressure water. A grid consisting of sixty $20 \times 20 \mathrm{~cm}$ sections was positioned against the profile wall to determine the spatial distribution of roots within a $2 \times 1.2 \mathrm{~m}$ area of the wall surface. The grid extended $1 \mathrm{~m}$ from the tree rows in either-direction and $1.2 \mathrm{~m}$ below the soil surface. Roots in each $20 \times 20 \mathrm{~cm}$ segment were counted and categorized by diameter ( $<2 \mathrm{~mm}, 2$ to $5 \mathrm{~mm}, 5$ to $10 \mathrm{~mm}$, and $>10 \mathrm{~mm}$ ). Root counts in grid segments of equal depth and distance from row middles (that is, on both sides of each tree) were combined when determining the average root concentrations. The distribution of thick diameter roots $(>2$ $\mathrm{mm})$ was similar to thin $(<2 \mathrm{~mm}$ in diameter) roots but comprised $<10 \%$ of the total root count. Thus, only data for roots in the thin-diameter class are reported.

For each treatment, root counts per $\mathrm{dm}^{2}$ were analyzed by fitting multiple regression equations using PROC REG of SAS (1982). The form of the regression equation was

$$
\begin{aligned}
\text { Roots }=\beta_{0} & \left.+\beta_{1} \text { Dist }+\beta_{2} \text { depth }+\beta_{3} \text { (depth }\right)^{-1} \\
& +\beta_{4} \text { Dist } \times(\text { depth })^{-1}
\end{aligned}
$$

where Dist and depth are factors measuring the distance from tree row middles in units of $10,30,50,70,90$, and $110 \mathrm{~cm}$, respectively. In the equation, $\beta_{0}$ represents a constant and the terms $\beta_{1}$ Dist and $\beta_{2}$ depth represent the linear effects of distance and depth, respectively, on root concentration, while the term $\beta_{3}(\text { depth })^{-1}$ represents a curvilinear (exponential) effect of depth on root concentration. The cross-product term $\beta_{4}$ Dist $\times(\text { depth })^{-1}$ represents an interaction between the effect of distance and the curvilinear effect of depth. Since the level of irrigation did not affect root distribution nor was there any evidence of interaction between planting treatment and irrigation level, the data for both irrigation levels were combined when fitting the regression equation above.

\section{Results}

1986 data. Vegetative growth of shoots was reduced by the NHS and FLT treatments. Diameter and length of primary shoots, number and combined length of second-order shoots, and total length of shoots were less for NHS and FLT trees than for controls (Table 1). The number of second-order shoots was influenced by planting treatment, but their mean length did not differ among treatments (data not reported).

Flower density (flowers per centimeter of shoot) and the number of flowers per node were higher $(P<0.01)$ for primary shoots than for second-order shoots with all treatments (Table 2). Across treatments, primary shoots had a significantly higher $(\mathrm{P}<0.0001)$ proportion of paired flowers with fewer single flowers per node than did second-order shoots. The percentage of nodes containing flowers was similar for primary and secondorder shoots for all treatments, although flower density was less for second-order shoots. 
Table 1. Effect of planting treatment on vegetative growth of 'Redhaven' peach trees.

\begin{tabular}{|c|c|c|c|c|c|c|c|c|}
\hline \multirow{2}{*}{$\begin{array}{l}\text { Planting } \\
\text { treatment } \\
\text { Control }\end{array}$} & \multirow{2}{*}{$\begin{array}{r}\begin{array}{c}\text { Shoot } \\
\text { diam } \\
(\mathrm{cm})\end{array} \\
1.1 \mathrm{a}^{z}\end{array}$} & \multicolumn{2}{|c|}{$\begin{array}{l}\text { Length of } \\
\text { primary } \\
\text { shoots } \\
(\mathrm{cm}) \\
\end{array}$} & \multicolumn{2}{|c|}{$\begin{array}{l}\text { Combined length } \\
\text { of second-order } \\
\text { shoots } \\
(\mathrm{cm})\end{array}$} & \multicolumn{2}{|c|}{$\begin{array}{l}\text { Length of primary } \\
\text { plus second-order } \\
\text { shoots } \\
(\mathrm{cm})\end{array}$} & \multirow{2}{*}{$\begin{array}{c}\begin{array}{c}\text { Second-order } \\
\text { laterals } \\
\text { (no.) }\end{array} \\
6.2 \mathrm{a}\end{array}$} \\
\hline & & 101 & a & 167 & a & 269 & $\mathrm{a}$ & \\
\hline Auger & $1.0 \mathrm{ab}$ & 90 & $a b$ & 109 & bc & 1 & $b c$ & \\
\hline Raised bed & $1.0 \mathrm{ab}$ & 96 & $\mathbf{a}$ & 131 & $a b$ & 227 & $a b$ & $5.0 \mathrm{ab}$ \\
\hline NHS & $0.9 \mathrm{bc}$ & 80 & $\mathrm{bc}$ & 77 & $\mathrm{bc}$ & 157 & $\mathrm{c}$ & $3.4 \mathrm{~b}$ \\
\hline FLT & $0.8 \mathrm{c}$ & 73 & $\mathrm{c}$ & 68 & c & 142 & c & $3.3 \mathrm{~b}$ \\
\hline$S E$ & 0.04 & 3. & & 18.9 & & 21.9 & & 0.6 \\
\hline
\end{tabular}

${ }^{2}$ Means separation within columns by Duncan's multiple range test, $P=0.05$.

Table 2. Effect of planting treatment on flowering characteristics of 'Redhaven' peach trees.

\begin{tabular}{|c|c|c|c|c|c|}
\hline $\begin{array}{l}\text { Planting } \\
\text { treatment }\end{array}$ & $\begin{array}{c}\text { Flower } \\
\text { density } \\
\text { (flowers/cm } \\
\text { shoot) }\end{array}$ & $\begin{array}{c}\text { Flowers per } \\
\text { node (no.) }\end{array}$ & $\begin{array}{c}\text { Single } \\
\text { flowers' } \\
(\% \text { of total }) \\
\end{array}$ & $\begin{array}{c}\text { Paired } \\
\text { flowers }^{y} \\
(\% \text { of total }) \\
\end{array}$ & $\begin{array}{c}\text { Nodes } \\
\text { containing } \\
\text { flowers } \\
(\% \text { of total }) \\
\end{array}$ \\
\hline \multicolumn{6}{|c|}{ Primary shoots } \\
\hline Control & $0.18 b^{x}$ & $0.34 \mathrm{~b}$ & $51 \mathrm{a}$ & $49 \mathrm{ab}$ & $25 \mathrm{~b}$ \\
\hline Auger & $0.16 \mathrm{~b}$ & $0.28 \mathrm{~b}$ & $53 \mathrm{a}$ & $47 \mathrm{~b}$ & $21 \mathrm{~b}$ \\
\hline Raised bed & $0.20 \mathrm{~b}$ & $0.36 \mathrm{~b}$ & $50 a b$ & $50 \mathrm{ab}$ & $26 \mathrm{~b}$ \\
\hline NHS & $0.18 \mathrm{~b}$ & $0.30 \mathrm{~b}$ & $51 \mathrm{a}$ & $49 \mathrm{ab}$ & $22 \mathrm{~b}$ \\
\hline FLT & $0.27 \mathrm{a}$ & $0.48 \mathrm{a}$ & $42 \mathrm{~b}$ & $57 \mathrm{a}$ & $34 \mathrm{a}$ \\
\hline \multicolumn{6}{|c|}{ Second-order shoots } \\
\hline Control & $0.14 \mathrm{ab}$ & $0.24 \mathrm{ab}$ & $87 \mathrm{a}$ & $14 \mathrm{a}$ & $22 b$ \\
\hline Auger & $0.12 \mathrm{~b}$ & $0.21 \mathrm{~b}$ & $86 \mathrm{a}$ & $14 \mathrm{a}$ & $19 \mathrm{~b}$ \\
\hline Raised bed & $0.16 \mathrm{ab}$ & $0.26 \mathrm{ab}$ & $90 \mathrm{a}$ & $10 \mathrm{a}$ & $25 \mathrm{ab}$ \\
\hline NHS & $0.13 \mathrm{~b}$ & $0.20 \mathrm{~b}$ & $84 \mathrm{a}$ & $16 \mathrm{a}$ & $17 \mathrm{~b}$ \\
\hline FLT & $0.20 \mathrm{a}$ & $0.32 \mathrm{a}$ & $94 \mathrm{a}$ & $7 \mathrm{a}$ & $31 \mathrm{a}$ \\
\hline
\end{tabular}

${ }^{2}$ Single flowers $=$ one flower per node.

${ }^{y}$ Paired flowers $=$ two flowers per node.

${ }^{\mathrm{x}}$ Mean separation (within groups of five) by Duncan's multiple range test, $P=0.05$.

Of the planting treatments studied, only the FLT treatment consistently affected flowering characteristics of peach shoots. Flower density, number of flowers per node, and percentage of nodes containing flowers were higher for primary shoots of FLT trees than for primary shoots of any other treatment. For secondorder shoots, flower density, number of flowers per node, and percentage of nodes containing flowers were higher for FLT trees than for auger or NHS trees.

1987 Data. The total length of shoots increased curvilinearly ( $\mathrm{P}<0.0001)$ with increasing LCA for control, FLT, and NHS treatments (Fig. $1 \mathrm{~A}$ and B). The curves in Fig. 1 were generated by back-transforming from the fitted simple regression equations in the natural $\operatorname{logs}$ to produce curvilinear equations for total shoot length $\left(\mathrm{TSL}=\mathrm{e}^{\ln T \mathrm{TL}} \mathrm{e}^{\mathrm{MSE} / 2}\right.$ ) in the original units (centimeters). The multiplicative constant $\mathrm{e}^{\mathrm{MSE} / 2}$ is a bias-reduction factor where MSE is the error mean square from the analysis of the total shoot length data. A test on the curvilinearity of the control and FLT equations showed that the degree of curvilinearity was significantly greater $(P>0.05)$ for the control trees. In fact, total shoot length was greater $(\mathrm{P}<0.05)$ for the control trees than for the FLT trees, particularly at the LCA values $>0.15 \mathrm{~cm}^{2}$.

The number and combined length of second-order shoots increased with increasing LCA more for control shoots than for NHS or FLT shoots (data not shown). Moreover, second-order lateral shoots developed at smaller LCA values for control and NHS trees than for FLT trees. Second-order lateral shoots were observed on primary shoots of control and NHS trees with LCA values $\geq 0.2 \mathrm{~cm}^{2}$ but were only observed on primary shoots of FLT trees when LCA values reached at least $0.4 \mathrm{~cm}^{2}$ (data not shown).

The length of primary shoots increased quadratically $(\mathrm{P}<$ 0.0001 ) with increasing LCA for control, FLT, and NHS treatments (Fig. $2 \mathrm{~A}$ and B). Across LCA values, the primary shoots were shorter for FLT shoots (Fig. 2A) than for NHS (Fig. 2B) or control (Fig. $2 \mathrm{~A}$ and $\mathrm{B}$ ) shoots $(\mathrm{P}<0.10)$.

Significant linear relationships $(P<0.0001)$ were found between the total number of flowers per shoot and LCA for all treatments (Fig. 3). The number of flowers increased linearly for all treatments with increasing LCA, but the rate of increase was greater for controls (Fig. $3 \mathrm{~A}$ and $\mathrm{B}$ ) than for FLT (Fig. $3 \mathrm{~A})$ trees $(P<0.05)$.

Root distribution. The total number of roots observed per tree during excavation differed significantly among the three treatments $($ control $=1051$, NHS $=848$, and FLT $=470)$. The relative number of roots in the various diameter classes was not affected by planting treatment or irrigation level (data not reported). Roots in the 0- to 2-mm-diameter class comprised the vast majority of the root system for all planting/irrigation level combinations, always totaling $>90 \%$ of the roots counted.

Root concentrations decreased with increasing soil depth and distance from tree rows for the three planting treatments. Surface plots of the root distributions of control, NHS, and FLT trees are shown in Fig. 4. These plots were generated from the 

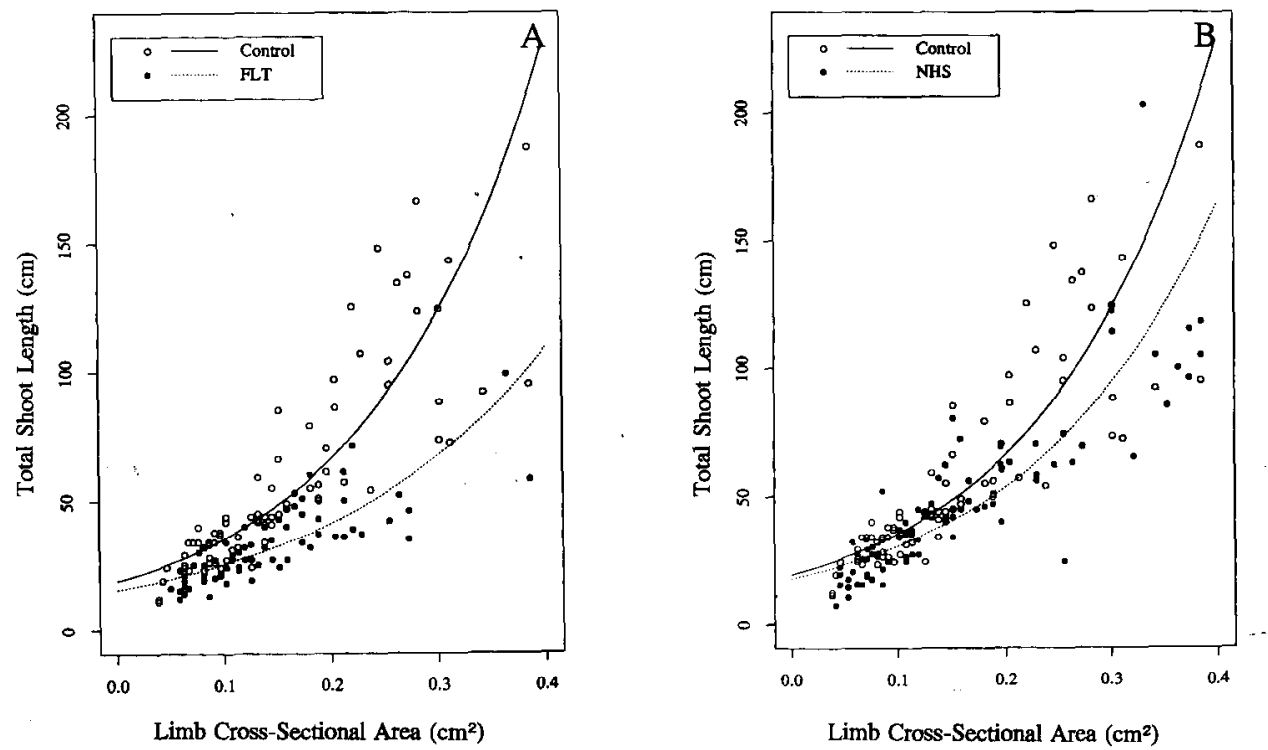

Fig. 1. Relationship between the total length of shoots (y) and limb cross-sectional area (x) for peach shoots of (A) control and FLT trees and (B) control and NHS trees. Estimated regression equations for the total length of shoots areas follows: For control, $y=\mathrm{e}^{2.903+6.214 x} \mathrm{e}^{0.0408}$, $\mathrm{R}^{2}=0.78$; for NHS, $\mathrm{y}=\mathrm{e}^{2.801}+{ }^{5.616 x} \mathrm{e}^{0.0349}, R^{2}=0.74$; for FLT, $\mathrm{y}=\mathrm{e}^{2.713+4.860 \mathrm{x}} \mathrm{e}^{0.0336}, R^{2}=0.65$.
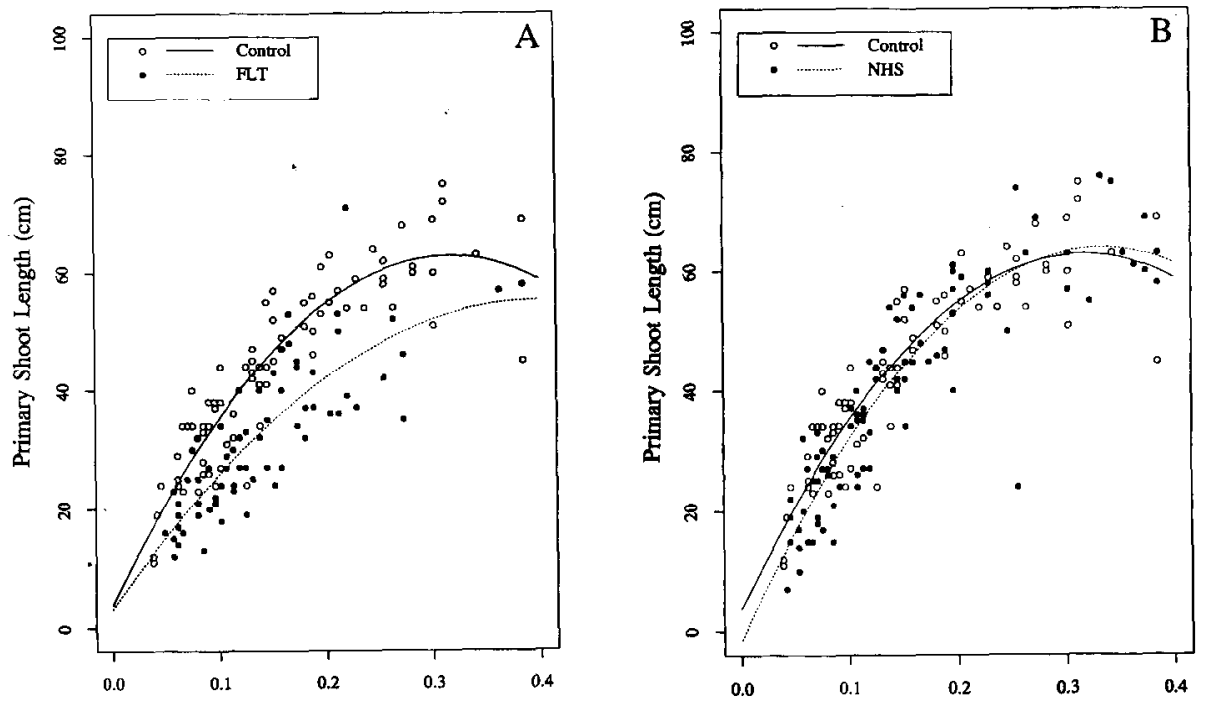

Fig. 2. Relationship between the length of primary shoots (y) and limb cross-sectional area (x) for peach shoots of (A) control and FLT trees and (B) control and NHS trees. Estimated regression equations for length of primary shoots are as follows: For control, $\mathrm{y}=3.82+372.09 \mathrm{x}$ $-586.07 \mathrm{x}^{2}, R^{2}=0.84$; for NHS, $\mathrm{y}=-1.36+391.31 \mathrm{x}-586.50 \mathrm{x}^{2}, R^{2}=0.81$; for $\mathrm{FLT}, \mathrm{y}=3.11+258.88 \mathrm{x}-320.40 \mathrm{x}^{2}, \mathrm{R}^{2}=$ 0.68 .

regression equations listed in Table 3 using the G3D procedure in SAS/GRAPH (SAS, 1982).

Overall, root distribution patterns were similar for the three treatments, although root counts tended to be higher for control (Fig. 4A) than for NHS (Fig. 4B) or FLT (Fig. 4C) trees. The exponential effect of depth on root concentration as reflected by the magnitude of the coefficient in the term $b_{3}(\text { depth })^{-1}$ was significantly $(\mathrm{P}<0.0001)$ greater for the control trees $(299.8)$ than for the NHS trees (227.4) and the FLT trees (246.3) Fig. $(4 \mathrm{~A}-\mathrm{C})$. Roots of the FLT trees were restricted laterally and vertically when compared with the other treatments. The decrease in root concentration with increased distance from the tree was significantly $(\mathrm{P}<0.001)$ greater with the FLT trees than with the control or NHS trees. Furthermore, the magnitude of the interaction effect of distance and (depth) ${ }^{-1}$ was signifi- cantly greater $(\mathrm{P}<0.001)$ with the FLT trees than with the control or NHS trees. This difference is evidenced by the surface shapes in Fig. 4, where the regression equation for the FLT root distribution predicts virtually no roots at distances $>80 \mathrm{~cm}$ from the tree rows or at soil depths $>80 \mathrm{~cm}$.

\section{Discussion}

Reduced widths of weed-free herbicide strips (NHS treatment) did not greatly affect root distribution patterns when compared with controls but did reduce the total number of roots observed per tree. The effects of permanent sod on root growth and distribution of fruit trees are not well understood. For apple, Coker (1959) and Rogers and Head (1970) found more branching and higher concentrations of fibrous roots under sod than 

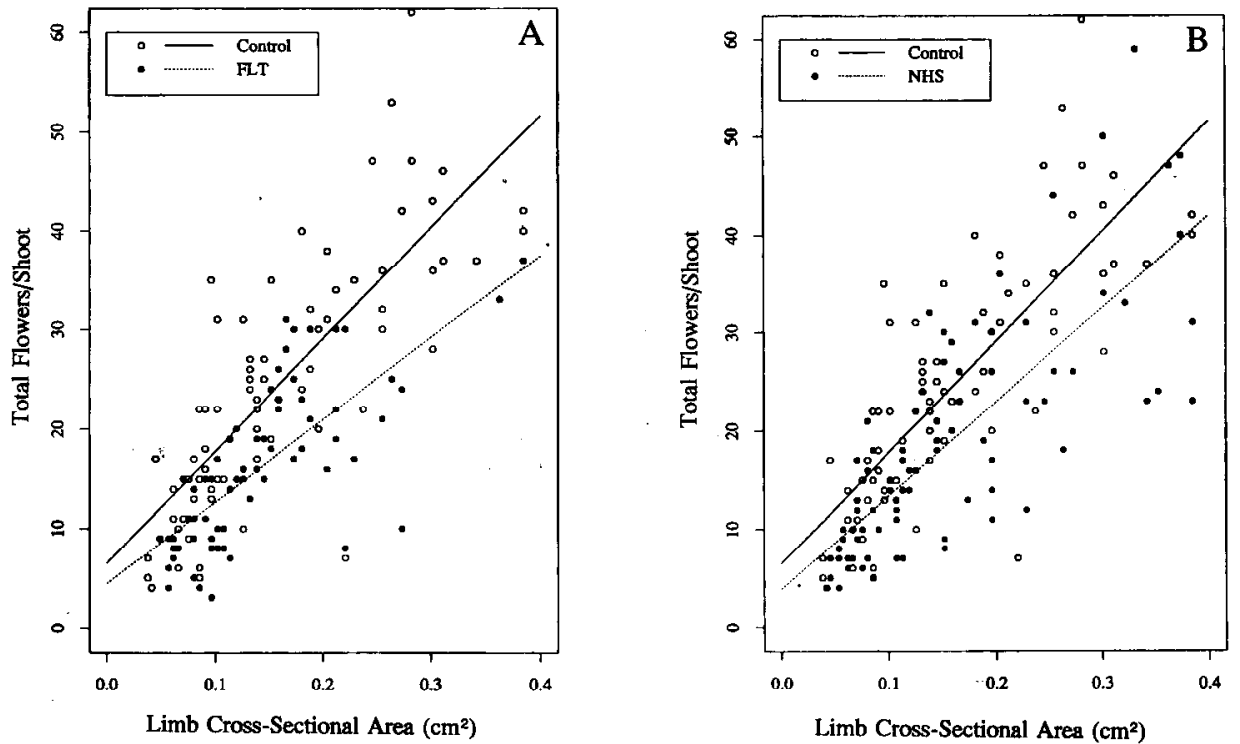

Fig. 3. Relationship between the total number of flowers per shoot (y) andlimb cross-sectional area (x) for peach shoots of(A) control and FLT trees and (B) control and M-IS trees. Estimated regression equations for total number of flowers per shoot are as follows: For control, $\mathrm{y}=6.48+112.84 \mathrm{x} R^{2}=0.63$; for NHS, $\mathrm{y}=3.89+95.26 \mathrm{x}, \mathrm{R}^{2}=0.61$; for FLT, $\mathrm{y}=4.43+82.56 \mathrm{x}, R^{2}=0.54$
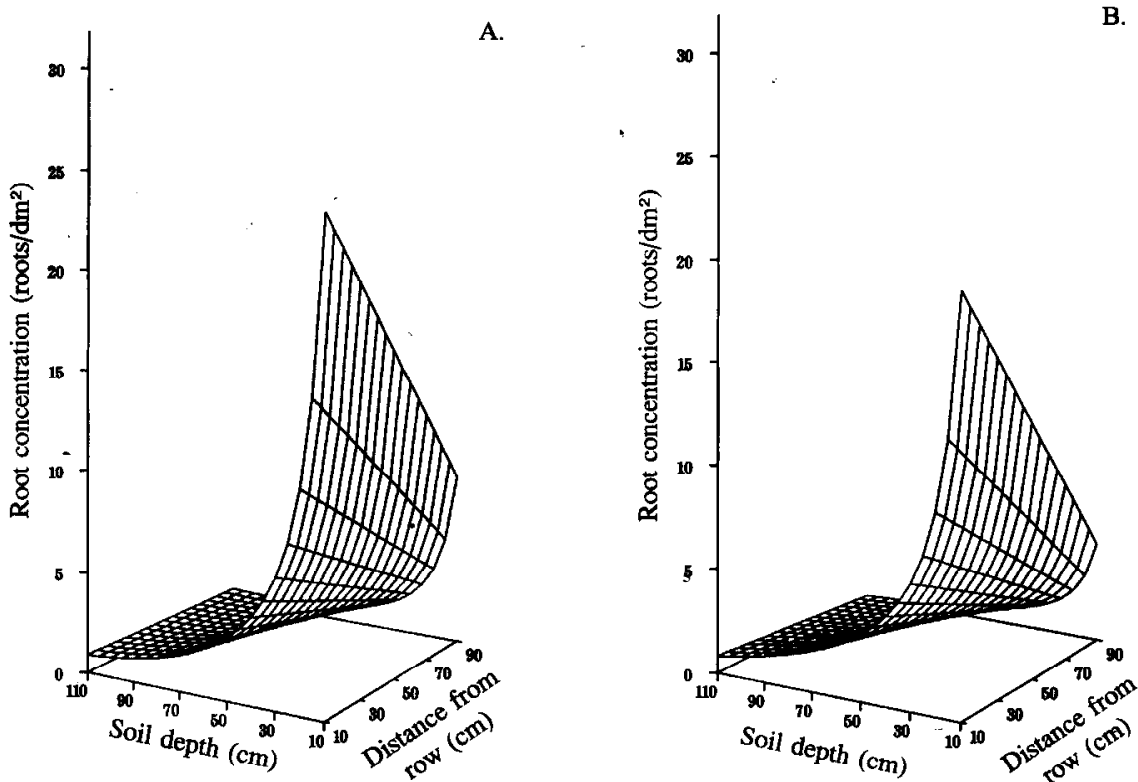

B.

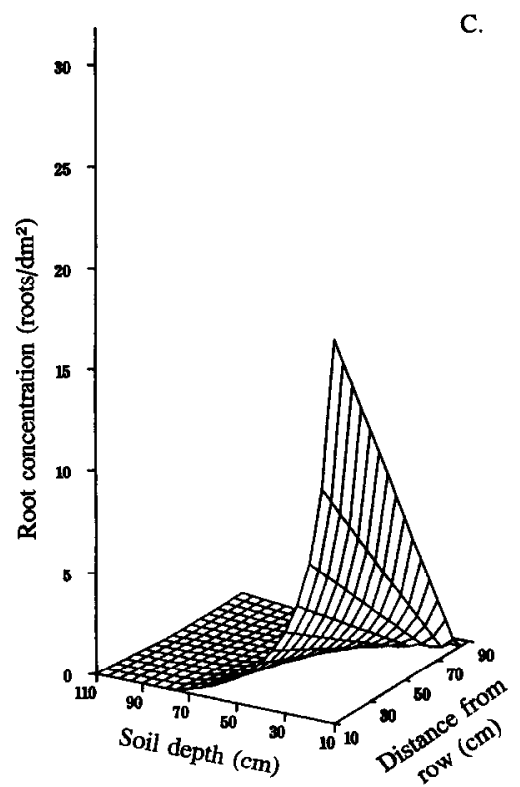

Fig.4. Root count response sufaces by soil depth and distance from tree rows for (A) control, (B) MS, and(C) FLT trees. See Table 3 for regression equation and coefficient estimates.

under cultivation. However, Weller (1971) reported that apple root concentrations were less under sod than under shallow cultivation or mulch. Glenn and Welker (1989) found that 'Kentucky-31' fescue sod reduced growth of peach. The lengths of peach roots $<1 \mathrm{~mm}$ in diameter were reduced beneath the sod and in the area between the sod and the tree. However, roots $>1 \mathrm{~mm}$ in diameter were not affected.

We have also observed less growth, lower per-tree yields, and lower yield efficiency for trees planted in fescue sod when the width of the herbicide strip was reduced from 1 to $0.5 \mathrm{~m}$ (Williamson and Coston, 1990). Those data suggest that competition from 'Kentucky-31' permanent sod is largely ineffective for controlling tree size when the ultimate objective is to increase yield efficiency. In the present study, mean values for most measures of shoot vegetative and reproductive growth were less for NHS trees than for control trees. However, the relationships of total shoot length, primary shoot length, or flower bud count with LCA were similar for NHS and control trees.

The greatest effect of planting treatment on root distribution and shoot development was with the FLT treatment. The number of roots observed outside vs. inside the soil zone defined by the fabric was not recorded. However, during excavation of the FLT trees, $60-\mathrm{cm}$ cross sections of the fabric were removed from the root zone and examined. Many fine roots grew into the fabric but few roots penetrated it. Where root penetration occurred, roots were girdled and root growth out of the fabric was suppressed. Regression analysis of root distribution data clearly indicates that roots of FLT trees were restricted, both 
Table 3. Coefficient estimates and significance levels $\operatorname{Pr}\left(\mathrm{F}>\mathrm{F}_{\mathrm{a}}\right)=$ $\alpha$ for the fitted regression equation Root concn $=b_{0}+b_{1}$ Dist + $\mathrm{b}_{2}$ depth $+\mathrm{b}_{3}(\text { depth })^{-1}+\mathrm{b}_{4}$ Dist $\times(\text { depth })^{-1}$ with the control, NHS, and FLT trees.

\begin{tabular}{|c|c|c|c|c|c|c|}
\hline \multirow{2}{*}{$\begin{array}{l}\text { Planting } \\
\text { treatment }\end{array}$} & \multicolumn{6}{|c|}{ Coefficient estimates } \\
\hline & $b_{0}$ & $\mathrm{~b}_{1}$ & $b_{2}$ & $b_{3}$ & $b_{4}$ & $R^{2}$ \\
\hline Control & $\begin{array}{c}-3.112 \\
0.0001\end{array}$ & $\begin{array}{l}0.016 \\
0.0387\end{array}$ & $\begin{array}{l}0.013 \\
0.0951\end{array}$ & $\begin{array}{r}298.107 \\
0.0001\end{array}$ & $\begin{array}{c}-2.104 \\
0.0001\end{array}$ & 0.8697 \\
\hline NHS & $\begin{array}{c}-1.061 \\
0.1040\end{array}$ & $\begin{array}{l}0.010 \\
0.1543\end{array}$ & $\begin{array}{c}-0.001 \\
0.8829\end{array}$ & $\begin{array}{c}227.409 \\
0.0001\end{array}$ & $\begin{array}{c}-1.967 \\
0.0001\end{array}$ & 0.8439 \\
\hline FLT & $\begin{array}{c}-4.269 \\
0.0001\end{array}$ & $\begin{array}{l}0.037 \\
0.0001\end{array}$ & $\begin{array}{l}0.014 \\
0.0364\end{array}$ & $\begin{array}{r}246.2665 \\
0.0001\end{array}$ & $\begin{array}{r}-2.844 \\
0.0001\end{array}$ & 0.8441 \\
\hline
\end{tabular}

laterally and vertically, when compared with control or NHS trees.

In sharp contrast to NHS trees, reductions in vegetative shoot growth of FLT trees were accompanied by enhanced reproductive growth. Values for flower density, flowers per node, and percentage of nodes containing flowers were higher for FLT trees than for NHS or control trees. The relationship of total shoot length and primary shoot length with LCA was also significantly different for FLT trees when compared with control or NHS trees. Richards and Rowe (1977) studied the effects of root restriction on hydroponically grown peach seedlings and concluded that peach roots exert hormonal control over shoot development. No attempt was made in our study. to measure hormone levels in tissues of plants subjected to different planting treatments. However, the differences in shoot growth and development observed among planting treatments were consistent with those growth effects often attributed to changes in plant hormone status.

Dorsey (1935) reported that nodal development of peach has a definite pattern that is related to vegetative vigor. He described five classes of nodal development on the bases of node complexity and arrangement of leaves, lateral shoots, and leaf and flower buds within the node. Many of the differences reported here for shoot growth and flower bud development of FLT (restricted) trees vs. control or NHS (nonrestricted) trees cannot be explained solely in terms of shoot vigor. Differences in growth and development were noted between FLT and NHS shoots across comparable LCA values, even though both treatments, on average, reduced vegetative growth relative to controls. FLT trees quickly filled their allotted space in the orchard and developed many of the desirable characteristics of fruit trees propagated on dwarfing or semi-dwarfing rootstock (Williamson and Coston, 1990). Although the physiological bases for these growth responses to root restriction remain unclear, tree size control by root restriction appears to be more consistent with the objective of increasing reproductive growth than does tree size control by competition from orchard floor vegetation.

\section{Literature Cited}

Bargioni, G., F. Loreti, and P.L. Pisani. 1983. Performance of peach and nectarine in a high-density system in Italy. HortScience 18: 143146.

Bargioni, G., F. Loreti, and P.L. Pisani. 1985. Ten years of research on peach and nectarine in a high-density system in the Verona area. Acts Hort. 173:299-304.

Bohm, W. 1979. Methods of studying root systems. Springer-Verlag, Berlin.

Chalmers, D., B. van den Ende, and L. van Heek. 1978. Productivity and mechanization of the Tatura Trellis orchard. HortScience 13:517521.

Chalmers, D. J., P.D. Mitchell, and L. van Heek. 1981. Control of peach tree growth and productivity by regulated water supply, tree density, and summer pruning. J. Amer. Soc. Hort. Sci. 106:307312.

Cockcroft, B. and J.C. Wallbrink. 1966. Soil properties and tree vigor in the Goulburn Valley. Austral. J. Expt. Agr. Animal Husbandry 6:204-208.

Coker, E.G. 1959. Root development of apple trees in grass and clean cultivation. J. Hort. Sci. 34:111-121.

Dolph, C.A. and E.L. Proebsting, Jr. 1989. Root confinement affects growth and physiology of sweet cherry and apple. ASHS 1989 Annu. Mtg., Tulsa, Okla., Prog. \& Abstr. p. 99.

Dorsey, M.J. 1935. Nodal development of the peach shoot as related to fruit bud formation. Proc. Amer. Soc. Hort. Sci. 33:245-257.

Erez, A. 1976. Meadow orchard for the peach. Scientia Hort. 5:4348

Erez, A. 1982. Peach meadow orchard: Two feasible systems. HortScience 17:138-142.

Erez, A. 1985. Peach meadow orchards. Acts Hort. 173:405-411.

Glenn, D.M. and W.V. Welker. 1989. Peach root development and tree hydraulic resistance under tall fescue sod. HortScience 24:117119.

Havis, L. 1938. Peach tree root distribution. Ecology 19:454-462.

Mitchell, P.D. and D.J. Chalmers. 1982. The effect of reduced water supply on peach tree growth and yields. J. Amer. Soc. Hort. Sci. 107:853-856.

Richards, D. and R.N. Rowe. 1977. Root-shoot interactions in peach: The function of the root. Ann. Bet. 41:1211-1216.

Rogers, W.S. and G.C. Head. 1970. Factors affecting the distribution and growth of roots of perennial woody species, p. 280-295. In: W.J. Whittington (ed.). Root growth. Butterworths, London.

SAS Institute. 1982. SAS user's guide: Statistics. SAS Institute, Inc., Cary, N.C.

Weller, F. 1971. A method of studying the distribution of absorbing roots of fruit trees. Expt. Agr. 7:351-361.

Williamson, J.G. and D.C. Coston. 1990. Planting method and irrigation rate influence vegetative and reproductive growth of peach planted at high density. J. Amer. Soc. Hort. Sci. 115:207-212. 